\title{
PENGARUH APLIKASI MOVING BED BIOFILM REACTOR (MBBR) UNTUK PENGOLAHAN LIMBAH AIR LINDI (LEACHATE) SECARA AEROBIK TERHADAP KUALITAS AIR
}

(The Effect of Application Moving Bed Biofilm Reactor (MBBR) To Leachate Wastewater Treatment Aerobically To Water Quality)

\author{
Sischa Anisa, Darwin ${ }^{1}$, Muhammad Yasar* \\ ${ }^{1}$ Program Studi Teknik Pertanian, Fakultas Pertanian, Universitas Syiah Kuala \\ Corresponding author: yasar.unsyiah@gmail.com
}

\begin{abstract}
Abstrak. Penelitian ini bertujuan untuk mengetahui efektivitas pengolahan air lindi (leachate) dengan proses aerob menggunakan aplikasi reaktor biofilm dan reaktor tanpa biofilm untuk mengurangi bahan pencemar pada lindi. Penimbunan sampah yang dilakukan setiap harinya di tempat pembuangan akhir (TPA) dapat menimbulkan masalah bagi lingkungan sekitarnya, dengan terbentuknya air lindi (leachate). Lindi yang terinfiltrasi akan mencemari air tanah. Pengolahan leachate sampah dilakukan secara fisika, kimia atau biologi tergantung pada karakteristik lindi. Kurangnya kandungan oksigen terlarut akan menghambat proses biodegradasi sehingga kandungan zat organik lindi akan meningkatmaka dilakukan uji coba pengolahan air lindi dengan teknologi aerasi menggunakan biofilm atau sistem pertumbuhan melekat MBBR untuk menurunkan kandungan bahan pencemar. Pengolahan dilakukan selama 10 hari olah menggunakan sistem kontinu, membandingkan reaktor tanpa biofilm (kontrol), reaktor MBBR menggunakan media k1 (kaldness) sebagai filter dan tempat melekatnya mikroorganisme serta reaktor MBBR menggunakan arang tempurung kelapa sebagai absorban. Volume yang digunakan 5 liter lindi untuk setiap reaktor. Dari pengolahan yang dilakukan diperoleh penurunan BOD adalah $64 \%, 73 \%$, dan $75 \%$; COD adalah mengalami kenaikan $8 \%$, $14,3 \%$, dan $35,8 \%$; TKN adalah $44,44 \%, 56,73 \%$, dan $75,7 \%$, Fe adalah $9,041 \mathrm{mg} / 1$ (influent); $8,033 \mathrm{mg} / \mathrm{l}$; $9,0543 \mathrm{mg} / \mathrm{l}$ dan $5,053 \mathrm{mg} / \mathrm{l}$.
\end{abstract}

Kata kunci : MBBR, Aerobik, Lindi.

\begin{abstract}
This study aims to determine the effectiveness of leachate with aerobic processes using biofilm reactors and reactors without biofilms to reduce pollutants in leachate. The landfill that is carried out every day in the landfill (TPA) can cause problems for the surrounding environment, with the formation of leachate (leachate). Infiltrated leachate will contaminate ground water. Processing of waste leachate is done in physics, chemistry or biology depending on leachate characteristics. Lack of dissolved oxygen will inhibit the biodegradation process so that the content of leachate organic matter will increase, then a trial of leachate treatment with aeration technology is carried out using a biofilm or MBBR's inherent growth system to reduce the pollutant content. Processing was carried out for 10 days using a continuous system, comparing the reactor without biofilm (control), the MBBR reactor using k1 (kaldness) as a filter and the attachment of microorganisms and the MBBR reactor using coconut shell charcoal as absorbent. The volume used is 5 liters of leachate for each reactor. From the processing carried out obtained a decrease in BOD is $64 \%, 73 \%$, and $75 \%$; COD has increase by $8 \%, 14.3 \%$, and $35.8 \%$; TKN is $44.44 \%, 56.73 \%$, and $75.7 \%$, Fe is $9.041 \mathrm{mg} / 1$ (influent); $8.033 \mathrm{mg} / 1 ; 9.0543 \mathrm{mg} / 1$ and $5.053 \mathrm{mg} / \mathrm{l}$.
\end{abstract}

Keywords: MBBR, Aerobic, Leachate

\section{PENDAHULUAN}

Lindi termasuk jenis limbah cair yang terbentuk dari cairan yang menginfiltrasi melalui tumpukan sampah yang berasal dari sumber eksternal berupa air hujan, drainase permukaan, dan cairan yang diproduksi dari dekomposisi sampah (Kusumawati, 2012). Lindi merupakan zat pencemar berbahaya karena memiliki karakteristik tingginya kandungan bahan organik, logam, asam, garam terlarut dan mikroorganisme. Tingginya kandungan bahan organik pada lindi dapat mempengaruhi konsentrasi oksigen terlarut dalam badan air sehingga meningkatkan eutrofikasi, turbiditas, dan pencemaran bahan kimia serta mikroorganisme yang mengganggu kehidupan makhluk hidup perairan. 
Pengolahan limbah cair dilakukan agar limbah tidak mengganggu lingkungan penerima limbah yang dapat dilakukan melalui tiga metode yaitu fisika, kimia, dan biologi (Siregar,2005). Pengolahan lindi umumnya dilakukan secara biologi dengan memanfaatkan aktifitas mikroorganisme untuk mendekomposisi zat atau senyawa berbahaya yang terdapat pada lindi. Pengolahan limbah cair secara biologi dapat berlangsung dengan dua lingkungan yaitu lingkungan aerobik atau lingkungan anaerobik (Djajadiningrat dan Wisjnusuprapto, 1991). Mikroorganisme yang terdapat pada lindi hidup dalam kondisi menggunakan udara atau aerobuntuk menguraikan senyawa organik dan anorganik pada lindi.

Pengolahan dilakukan menggunakan reaktor sistem pertumbuhan melekat (MBBR) yang memanfaatkan biofilm untuk memelihara mikroorganisme sebagai pengurai bahan pencemar, dengan media bioball dan kaldness (k1) serta arang. Penelitian ini bermaksud untuk melihat perbandingan efektivitas pengolahan antara reaktor konvensional atau reaktor tanpa biofilm dan reaktor MBBR menggunakan biofilm dalam menurunkan bahan pencemar organik dan anorganik pada limbah cair lindi.

\section{METODE PENELITIAN}

\section{Tempat dan Waktu}

Penelitian ini dilakukan di Laboratorium Teknik Pasca Panen Fakultas Pertanian Universitas Syiah Kuala Darussalam Banda Aceh.Penelitian ini dilaksanakan pada bulan Juli sampai September 2018.

\section{Alat dan Bahan}

Alat yang digunakan pada penelitian ini adalah benchtop meter (untuk analisis $\mathrm{pH}$, TDS, EC, dan Salt), aerator, powerhead pump (pompa celup), bioball, kaldness (K1), arang, selang, oven, furnance, timbangan analitik, jerigen, gelas ukur, gelas beker, kertas saring, dan sarung tangan. Bahan yang digunakan adalah air lindi, $\mathrm{HCl}$, dan Aquades.

\section{Pembuatan Alat}

Perakitan alat dilakukan dengan memasangkan aerator dan pompa celup serta botol plastik sebagai wadah media biofilm kaldness (K1) dan arang pada wadah plastik, kemudian pemasangan selang untuk mengalirkan air ke media filter dalam botol plastik.

\section{Pengambilan Bahan}

Lindi diambil dari TPA Gampong Jawa sebanyak 30 liter menggunakan Jerigen pada lokasi kolam penampungan lindi yang berasal dari pipa dibawah landfill. Lindi dianalisis untuk mengetahui tingkat kandungan bahan pencemar di Baristand Banda Aceh dengan parameter fisika (TDS, TSS dan VSS) dan kimia (pH, BOD, COD, TKN, EC, Fe, dan Salinitas). Selanjutnya dilakukan pengolahan menggunakan reaktor.

\section{Proses Pengolahan Secara Aerob dengan Sistem Kontinyu}

Proses aerob dengan sistem kontinyu menggunakan reaktor reaktor MBBR biofilm dan reaktor MBBR dengan arang serta reaktor konvensional tanpa biofilm sebagai kontrol dengan wadah plastik bervolume 10 liter. Selanjutnya di masukkan lindi dengan volume $5000 \mathrm{ml}$ atau 5 liter kedalam masing-masing reaktor. Diolah dengan HRT 10 hari. HRT atau Hydraulic Retention Time merupakan parameter penting untuk menentukan waktu yang dibutuhkan oleh mikroorganisme untuk tumbuh, dan waktu yang butuhkan untuk menguraikan bahan-bahan organik (Burke, 2010). Pengisian dan pengambilan sampel 
dilakukan satu kali sehari (1x24 jam) pada pukul 11.00 WIB dikedua reaktor. Selanjutnya dilakukan pengujian di Laboratorium untuk mendapatkan hasil pengukuran dan pengujian terhadap sampel lindi.

\section{HASIL DAN PEMBAHASAN}

\section{Deskripsi Wilayah}

TPA Gampong Jawa merupakan lokasi tempat pembuangan akhir sampah yang berada di Kota Banda Aceh. Seluruh sampah yang ada di dalam Kota Banda Aceh dibawa ke TPA Gampong Jawa. Secara geografis, TPA Gampong Jawa terletak diantara $112^{\circ} 37^{\prime} 58^{\prime \prime}$ BT-112 $38^{\prime} 01^{\prime \prime}$ BT dan $7^{\circ} 13^{\prime} 02^{\prime \prime}$ LS-7 $13^{\circ} 19^{\prime \prime}$ LS, dan berada di dekat muara sungai Krueng Aceh.

TPA Gampong Jawa pertama kali dibangun pada tahun 1994 dengan luas lahan 12 Ha. TPA ini sempat hancur saat terjadi bencana gempa dan tsunami tahun 2004, kemudian difungsikan kembali dan diperluas menjadi $15 \mathrm{Ha}$, akantetapi yang hanya digunakan sebanyak 9 Ha. Setelah di rehabilitasi pada tahun 2008 oleh Badan Rehabilitasi dan Rekonstruksi (BRR) Aceh-Niasmulai beroperasi pada januari 2009 dan dikelola oleh Dinas kebersihan dan Keindahan Kota (DK3) Banda Aceh.

Sistem pengolahan sampah yang dilakukan di TPA Gampong Jawa menggunakan sistem sanitary landfill dengan proses penumpukan sampah dengan penutupan tanah dan kompos. Di bawah sanitary landfill terdapat pipa yang terhubung ke kolam penampungan lindi. Lindi yang terinfiltrasi akan masuk ke pipa dan teralirkan ke kolam. Pengolahan lindi yang tertampung dikolam menggunakan sistem lagoon kolam-kolam dijadikan penampung untuk mengalirkan lindi.

\section{Karakteristik Lindi}

Berdasarkan penelitian yang telah dilakukan oleh Said dan Hartaja (2018), menentukan karakteristik lindi disetiap TPA berbeda-beda tergantung dari jenis sampah yang tertimbun, jenis tanah penutup landfill, $\mathrm{pH}$ dan kelembaban seta umur timbunan. Usia landfill mempengaruhi kualitas dan konsentrasi bahan organik yang ada pada lindi. Timbunan sampah di TPA Gampong Jawa berasal dari berbagai macam jenis sampah yang ada di kota Banda Aceh. Jenis sampah yang paling banyak adalah sampah sisa makanan dengan persentase sebanyak 34\% dari seluruh jenis sampah yang ada. Pengolahan lindi menitikberatkan pada penurunan kandungan bahan organik yang dapat dilihat dari paramameter $\mathrm{pH}, \mathrm{BOD}$, dan COD. Nilai BOD dan COD sangat penting untuk menentukan jenis pengolahan yang digunakan, karakteristik lindi dapat dilihat pada Tabel 1. Hasil pengujian laboratorium nilai BOD dan COD adalah 551,42 mg/l dan COD 4984,8 mg/l dan $\mathrm{pH} 8,08$, keduanya termasuk dalam kategori sedang dengan kisaran 1.000-10.000 untuk nilai COD dan kategori rendah dengan kisaran 220-750 mg/l untuk nilai BOD.Proses biologis aerob digunakan untuk pengolahan sampah dilihat dari nilai BOD $<3000 \mathrm{mg} / 1$ (Said dan Hartaja, 2018). Nilai ini sesuai dengan hasil uji BOD yang diperoleh yaitu $551,42 \mathrm{mg} / \mathrm{l}$. Nilai ini tergolong kategori rendah dan sedang, dikarenakan umur TPA yang hampir 10 tahun sehingga menyebabkan kandungan bahan organik pada lindi sudah berkurang.

\section{Derajat Keasaman (pH)}

Umumnya nilai $\mathrm{pH}$ lindi diatas 7 tergolong basa. Asam atau basanya nilai $\mathrm{pH}$ lindi tergantung dari karaketeristik sampah yang membentuk lindi. Hasil penelitian diperoleh nilai $\mathrm{pH}$ awal lindi TPA Gampong Jawa (influent) adalah 8,08 yang tergolong basa. Kenaikan $\mathrm{pH}$ lindi terjadi karena pengaruh aerasi yang meningkatkan oksigen terlarut 
pada lindi. Hal ini diperkuat oleh Hunt (1996) yang menyatakan aerasi ditujukan untuk memperluas muka kontak air dengan udara yang bermanfaat untuk mengembangkan bakteri aktif sebagai pengurai untuk menurunkan konsentrasi zat pencemar organik dalam limbah cair. Nilai $\mathrm{pH}$ hasil pengolahan dari tiga reaktor menunjukkan kenaikan nilai $\mathrm{pH}$ walaupun menggunakan media yang berbeda. Pada pengolahan menggunakan MBBR nilai $\mathrm{pH}$ pada hari ke-10 adalah 9,44. Nilai $\mathrm{pH}$ menggunakan pengolahan MBBR arang dengan nilai $\mathrm{pH}$ akhir 9,11. Sedangkan nilai $\mathrm{pH}$ pada reaktor kontrol tanpa biofilm juga mengalami kenaikan menjadi 9,53. Menurut Pohland dan Harper (1985) nilai pH air lindi pada tempat pembuangan sampah perkotaan berkisar antara 1,5-9,5. Dari ketiga nilai $\mathrm{pH}$ akhir (Effluent), nilai $\mathrm{pH}$ pada reaktor pengolahan MBBR arang masih berada dibawah ambang batas nilai $\mathrm{pH}$ yaitu 9,11 sedangkan nilai $\mathrm{pH}$ akhir pada reaktor kontrol sedikit melebihi ambang batas nilai $\mathrm{pH}$ yang ditentukan. Jadi dapat disimpulkan aerasi meningkatkan nilai $\mathrm{pH}$ walaupun setelah dilakukan pengolahan baik itu pada pengolahan konvensional atau tanpa biofilm maupun dengan menggunakan media seperti MBBR dan arang untuk media biofilm.

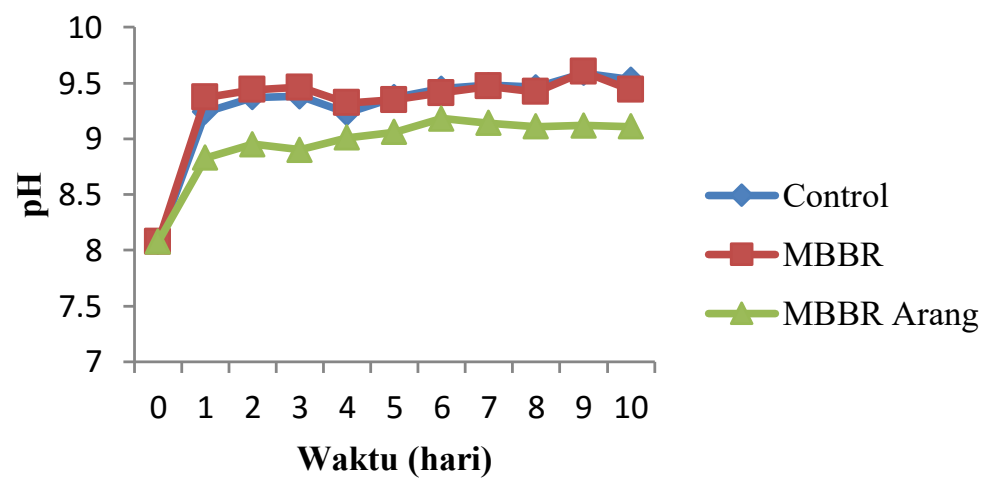

Gambar 1. Hasil analisis Effluent $\mathrm{pH}$ lindi harian setelah pengolahan

Tabel 1. Kategori Kekuatan Organik Lindi

\begin{tabular}{ccc}
\hline Katergori & \multicolumn{2}{c}{ Kisaran konsentrasi (mg/L) } \\
\cline { 2 - 3 } Kekuatan Lindi & COD & BOD5 \\
\cline { 2 - 3 } Rendah & $<1000$ & $220-750$ \\
Sedang & $1000-10000$ & $750-1500$ \\
Tinggi & $>10000$ & $1500-36000$ \\
\hline
\end{tabular}

\section{Biological Oxygen Demand (BOD)}

Nilai BOD tidak hanya menunjukkan jumlah oksigen tapi juga dapat diartikan sebagai gambaran jumlah bahan organik yang mudah terurai (biogedradable organic) yang ada diperairan (Mays, 1996). Kandungan BOD yang ada pada lindi umumnya $3500 \mathrm{mg} / \mathrm{l}$ (Aziz, 2010).Hasil pengujian laboratorium nilai kandungan BOD pada lindi di TPA Gampong Jawa adalah 551,42 mg/l nilai ini tidak tinggi karena pengaruh umur TPA, tapi masih belum sesuai standar baku mutu lindi yaitu $150 \mathrm{mg} / \mathrm{l}$. Setelah diolah dengan metode MBBR atau penggunaan media melekat BOD pada lindi berhasil direduksi menjadi 150,05 $\mathrm{mg} / \mathrm{l}$ dengan removal sebesar $73 \%$ sedangkan pengolahan MBBR arang berhasil direduksi menjadi 138,22 mg/l atau dengan removal sebesar 75\% nilai ini lebih tinggi dibandingkan dengan dengan nilai pengolahan menggunakan MBBR. Hal ini dikarenakan karbon arang mampu menyerap lebih banyak zat bahan organik selain itu arang tempurung kelapa juga mampu menyerap anion, kation dan molekul dalam bentuk senyawa organik maupun anorganik. Banyaknya biofilm yang terbentuk pada arang menjadikan mikroorganisme 
aktif lebih banyak mereduksi bahan organik.Hasil akhir (effluent) pengolahan dari MBBR dan arang berhasil menguraikan bahan organik yang ada pada lindi mencapai standar baku mutu limbah, dibandingkan dengan pengolahan yang dilakukan reaktor tanpa biofilm (konvensional) yang bisa menguraikan bahan organik lindi menjadi 196,22 mg/l dengan removal $64 \%$.

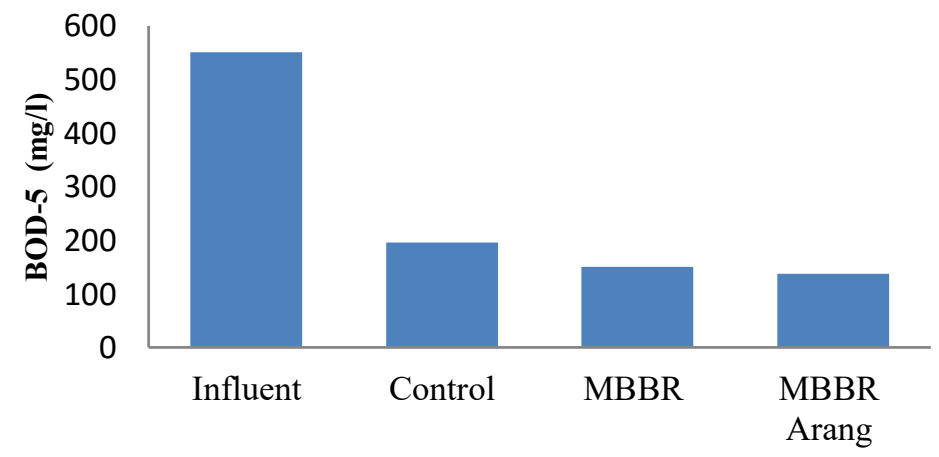

Gambar 2. Hasil analisis BOD-5 lindi awal dan akhir pengolahan

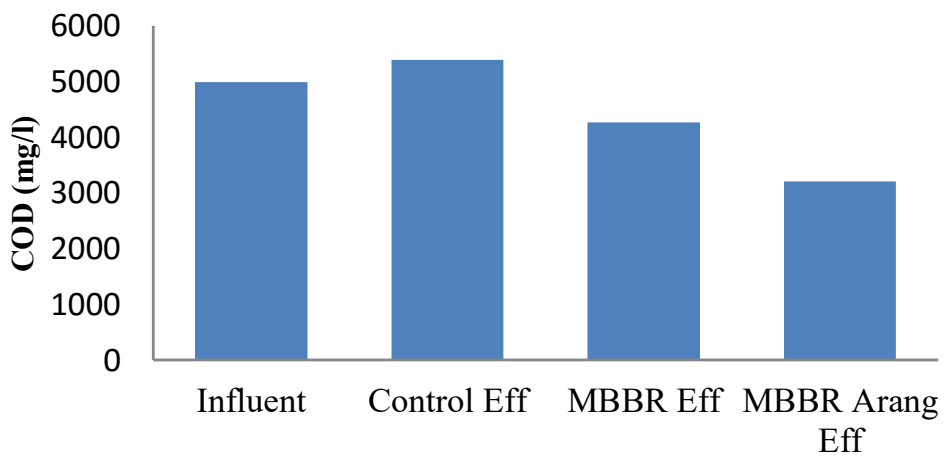

Gambar 3. Hasil analisis COD lindi awal dan akhir pengolahan

\section{Chemical Oxygen Demand (COD)}

COD menunjukkan kandungan jumlah oksigen yang diperlukan untuk mengoksidasi bahan organik yang terdapat pada limbah cair. Menurut Moertinah (2010) semakin tinggi COD semakin tinggi pula tingkat pencemaran air limbah. Nilai COD pada lindi awal TPA Gampong Jawa adalah 4984,8 mg/l nilai ini termasuk kategori sedang untuk kategori kekuatan bahan organik yang ada pada lindi (tabel 1), karenanya perlu dilakukan pengolahan untuk menurunkan nilai COD agar sesuai dengan standar baku mutu lindi adalah $300 \mathrm{mg} / \mathrm{l}$. Hasil pengolahan untuk menurunkan bahan organik pada lindi dapat dilihat pada Gambar 3. Pengolahan menggunakan MBBR dapat menurunkan COD menjadi $4268,72 \mathrm{mg} / \mathrm{l}$ dengan removal sebesar 14,3\%. Sedangkan hasil dari pengolahan MBBR arang adalah $3200 \mathrm{mg} / \mathrm{l}$ dengan removal sebesar 35,8\%. Nilai COD dari kedua jenis pengolahan biofilm lebih banyak mengalami degradasi dibandingkan dengan pengolahan konvensional atau reaktor kontrol.Dapat dilihat pada grafik pengolahan konvensional atau reaktor kontrol memiliki nilai 5386,8 mg/l, nilai ini lebih tinggi dibandingkan nilai lindi awal sebelum diolah, peningkatan nilai COD dikarenakan pengaruh dari kandungan bahan organik yang sulit terurai (nonbiodegradable). Dari ketiga perlakukan yang dilakukan pada pengolahan reaktor kontrol, MBBR, dan MBBR arang, removal COD yang diperoleh untuk reaktor kontrol (konvensional) sangat sedikit karena tidak berhasil diturunkan tapi mengalami peningkatan sebesar $8 \%$ dari influent lindi.Akan tetapi proses pengolahan menggunakan MBBR arang bisa dimanfaatkan untuk untuk proses pengolahan limbah 
dikarenakan tingkat persentase removal yang tinggi dibandingkan dengan pengolahan reaktor kontrol dan MBBR.

\section{Total Kjedahl Nitrogen (TKN)}

Total Kjeldahl Nitrogen (TKN) adalah parameter yang ditetapkan U.S EPA untuk mengukur kandungan nitrogen dan ammonia bahan organik. Berdasarkan penelitian yang telah dilakukan Qdais (2008), untuk TPA yang masih baru nilai TKN berkisar $100 \mathrm{mg} / \mathrm{l}$ sementara TPA yang sudah tua berkisar $2000 \mathrm{mg} / \mathrm{l}$. Nilai TKN lindi di TPA Gampong Jawa setelah diuji adalah $594 \mathrm{mg} / \mathrm{l}$. Menurut peraturan baku mutu lindi, kandungan nitrogen diukur sebagai N-Total yang merupakan jumlah TKN, NO3, dan NO2. Total-N yang diijinkan adalah $60 \mathrm{mg} / \mathrm{l}$. Untuk mendegradasi kandungan nitrogen pada lindi dilakukan pengolahan menggunakan sistem pertumbuhan media melekat atau biofilm dengan media yang berbeda. Dari hasil pengolahan yang dilakukan selama 10 hari diperoleh hasil TKN dengan menggunakan MBBR adalah $257 \mathrm{mg} / \mathrm{l}$ dengan removal sebesar $44 \%$ nitrogen yang berhasil didegradasi, sedangkan dengan pengolahan arang adalah $144 \mathrm{mg} / \mathrm{l}$ dengan removal sebesar 75,7\%. dari hasil pengolahan tersebut dapat dilihat bahwa pengolahan MBBR dan MBBR arang lebih efektif dibandingkan pengolahan konvensional dan media MBBR. Hal ini karena arang mampu menyerap bahan organik lebih banyak selain menjadi media tempat melekatnya biofilm, sedangkan k1 berfungsi sebagai media bahan anorganik yang juga digunakan untuk melekatnya biofilm seperti filter. Didukung oleh Hungtae (1966) terbentuknya biofilm pada media arang dan k1 menandakan semakin banyak mikroorganisme aktif yang terbentuk, mikroorganisme menggunakan nitrogen untuk membentuk sel tubuhnya yang berasal dari ammonia.

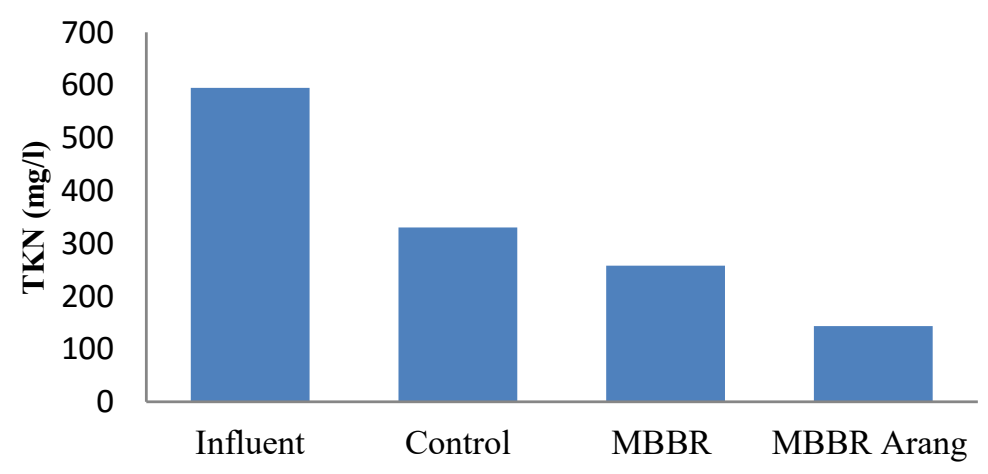

Gambar 4. Hasil analisis TKN lindi awal dan akhir pengolahan

\section{Besi (Fe)}

Kandungan Fe yang diperbolehkan pada lindi sudah ditetapkan oleh Peraturan Menteri Lingkungan Hidup Nomor 5 Tahun 2014 yaitu 5 mg/l. Jumlah kandungan Fe pada lindi di TPA Gampong Jawa setelah analisis adalah 9,041 mg/l, dimana jumlah ini melebihi dari standar baku yang telah ditetapkan oleh Menteri Lingkungan Hidup.Selain itu warna lindi yang hitam kecoklatan juga menandakan bahwa lindi mengandung besi yang tinggi. Oleh karenanya perlu dilakukan pengolahan untuk menurunkan kandungan $\mathrm{Fe}$ agar aman dibuang ke lingkungan.Dari hasil pengolahan yang telah dilakukan menggunakan pengolahan konvensional atau reaktor kontrol yang hanya menggunakan aerator berhasil menurunkan nilai Fe pada lindi menjadi $8,033 \mathrm{mg} / \mathrm{l}$. Pada pengolahan reaktor MBBR dengan filter arang berhasil didegradasi menjadi 5,053 mg/l, nilai ini sudah memenuhi nilai Fe yang ditetapkan.Menurut Abuzar (2012) penurunan nilai Fe terjadi karena aerasi yang terjadi pada proses pengolahan, dimana fungsi utama aerasi adalah 
untuk melarutkan oksigen dalam air sehingga kadar $\mathrm{Fe}$ dalam air akan mengalami penurunan. Sedangkan pada pengolahan reaktor MBBR terjadi peningkatan nilai $\mathrm{Fe}$ menjadi 9,543 $\mathrm{mg} / \mathrm{l}$, kenaikan ini disebabkan oleh beberapa faktor seperti kejenuhan oksigen, kenaikan suhu (Abuzar dkk, 2012) karena pada proses ada pengaruh dari filter air yang secara tidak langsung dapat meningkatkan jumlah oksigen.Dari ketiga perlakuan pengolahan, reaktor MBBR dengan filter arang lebih banyak menurunkan kandungan Fe pada lindi hal ini dikarenakan pengaruh dari pori-pori arang yang menyerap bahan anorganik pada lindi.

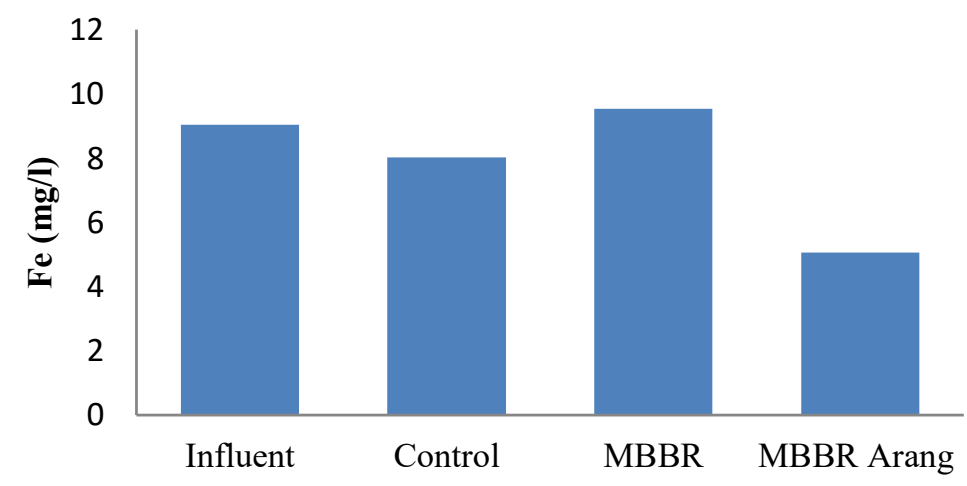

Gambar 5. Hasil analisis besi (Fe) lindi awal dan akhir pengolahan

\section{Total Padatan Terlarut (TDS), Electrical Conductivity (EC), dan Salinitas}

Ketiga parameter diatas merupakan parameter yang digunakan untuk mengetahui jumlah garam mieral yang ada pada lindi. dari hasi pengolahan yang dilakukan selama 10 hari, diketahui bahwa grafik nilai ketiga parameter mengalami kenaikan dan pola yang sama (lihat pada Gambar 6). Hal ini dikarenakan ketiga parameter saling berhubungan.

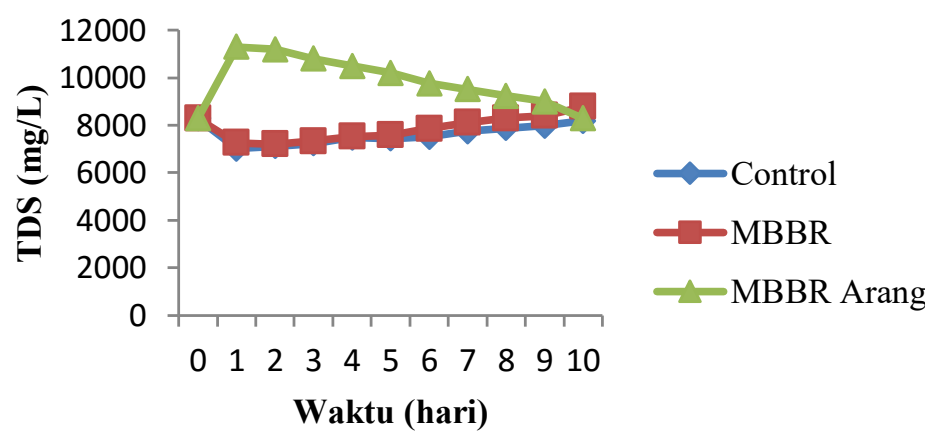

(a)

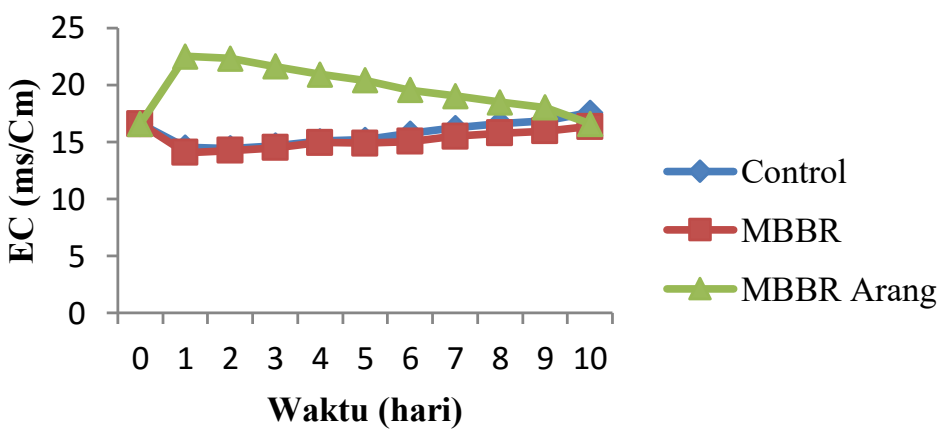

(b) 


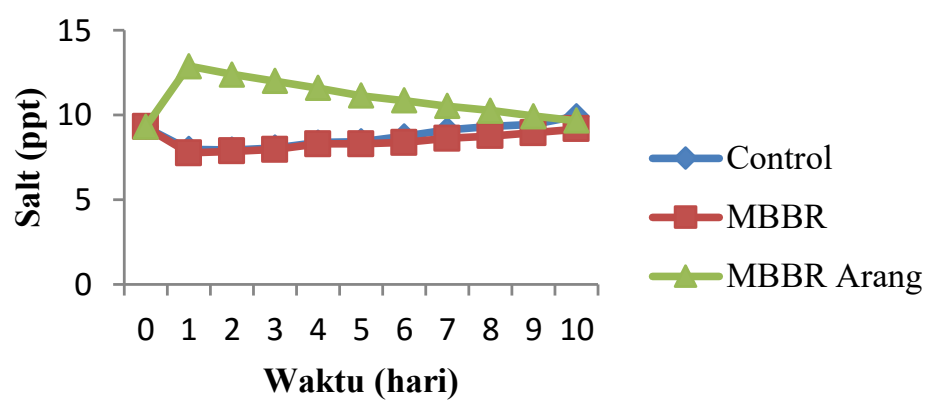

(c)

Gambar 6.(a) Kandungan EffluentTotal Padatan Terlarut lindi harian, (b) Kandungan Electrical Conductivity lindi harian, (c) Kandungan salinitas lindi harian

Kandungan TDS pada lindi awal adalah $8.290 \mathrm{mg} / \mathrm{l}$. Berdasarkan grafik, kandungan TDS setelah diolah 10 hari dengan menggunakan sistem pertumbuhan melekat atau biofilm sistem MBBR mengalami peningkatan pada hari ke-10 menjadi $8.780 \mathrm{mg} / \mathrm{l}$. Sedangkan pada pengolahan MBBR arang tidak mengalami perubahan nilai effluent sama dengan nilai influent yaitu $8.290 \mathrm{mg} / \mathrm{l}$. Nilai reaktor kontrol hanya menjadi pembanding pengolahan yang dilakukan tanpa biofilm untuk melihat keefektifan pengolahan yang ternyata memiliki pengaruh yang sama dengan nilai effluent TDS pada pengolahan MBBR yang dapat dilihat pada gambar 6 (a). Dari grafik pada, dapat dilihat peningkatan dan penurunan nilai EC pada lindi mirip dengan grafik pengukuran nilai TDS pada Gambar 6 (b). Dimana pada pengolahan menggunakan media arang pada hari pertama terjadi peningkatan sebesar $22,5 \mathrm{mS} / \mathrm{cm}$ dari nilai influent lindi $16,58 \mathrm{mS} / \mathrm{cm}$., kemudian turun pada pengolahan hari ke-10 menjadi $16,58 \mathrm{mS} / \mathrm{cm}$.

Nilai influent dan effluent lindi pada pengolahan dengan MBBR arang tidak berubah, sedangkan pengolahan menggunakan MBBR hari pertama nilai EC mengalami penurunan menjadi $14,04 \mathrm{mS} / \mathrm{cm}$, kemudian turun pada hari ke-10 menjadi $16,35 \mathrm{mS} / \mathrm{cm}$. Sedangkan pada pengolahan reaktor kontrol hasil pengolahan sama seperti pengolahan dengan sistem MBBR tapi hasil effluent reaktor kontrol adalah $17,55 \mathrm{mS} / \mathrm{cm}$ nilai ini lebih tinggi dibandingkan dengan nilai pada pengolahan MBBR dan pengolahan MBBR dengan filter arang.Salinitas terjadi ketika air mengandung kadar mineral tinggi dan menambah kadar garam tanah. Apabila lindi dengan kadar garam yang tinggi masuk keperairan yang digunakan untuk irigasi maka akan menggganggu pertumbuhan tanaman. Mikroorganisme membutuhkan salinitas dalam jumlah kecil. Nilai salinitas awal (influent) lindi adalah 9,3 ppt, setelah diolah menggunakan reaktor MBBR nilai salinitas pada lindi akhir (effluent) adalah 9,18 ppt, yang menunjukkan terjadinya peningkatan.Untuk pengolahan menggunakan reaktor kontrol atau konvensional nilai salinitas akhir mengalami peningkatan menjadi 9,94 pada hari ke-10. Sedangkan pada pengolahan menggunakan MBBR dengan filter arang nilai akhir (effluent) pengolahan menjadi 9,67 ppt. Hasil ketiga pengolahan menunjukkan terjadinya peningkatan salinitas. Jika salinitas tinggi, maka akan menyebabkan plasmolisis pada mikroorganisme. Jika kadar garam tinggi, maka bakteri memerlukan energi tambahan untuk fiksasi karbon dan mempertahankan tekanan osmotik.

\section{Total padatan tersuspensi (TSS) dan Total padatan teruap (VSS)}

Nilai TSS tertinggi berdasarkan standar baku mutu lindi yang ditetapkan oleh Menteri Lingkungan Hidup dan Kehutanan adalah 100 mg/l. Kandungan TSS pada influent lindi TPA Gampong Jawa adalah $70 \mathrm{mg} / \mathrm{l}$, nilai tersebut berada dibawah nilai standar baku mutu lindi. Pengukuran TSS dilakukan untuk memperkirakan kebutuhan bahan kimia atau 
koagulan dalam membantu proses pengendapan.Melihat banyaknya jumlah bahan tersuspensi yang dapat menyebabkan kekeruhan pada air. Pengolahan yang dilakukan menggunakan reaktor MBBR mengalami penurunan menjadi $60 \mathrm{mg} / \mathrm{l}$ sedangkan pada reaktor MBBR arang menjadi $55 \mathrm{mg} / \mathrm{l}$, begitu juga dengan reaktor kontrol tanpa biofilm kandungan TSS menjadi $65 \mathrm{mg} / \mathrm{l}$. penurunan nilai TSS karena pengaruh dari aerasi.Adanya masukan oksigen pada lindi akan dapat menghancurkan endapan yang menggumpal sehingga akan mempermudah penyerapan oksigen dan bakteri aerob yang berfungsi sebagai pengurai dapat tumbuh dengan baik dan semakin banyak bakteri pengurai yang menguraikan endapan yang tergumpal nilai TSS juga akan menurun. Hasil ketiga pengolahan nilai TSS yang dihasilkan masih aman karena berada dibawah nilai baku mutu, sehingga dapat dikatakan kandungan TSS pada lindi masih aman untuk dibuang ke lingkungan.

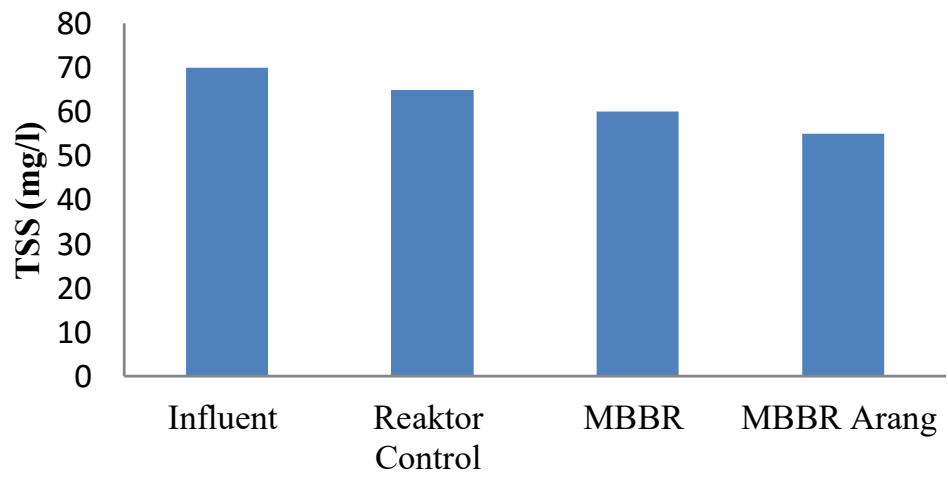

Gambar 7. Hasil analisis padatan tersuspensi lindi awal dan akhir pengolahan

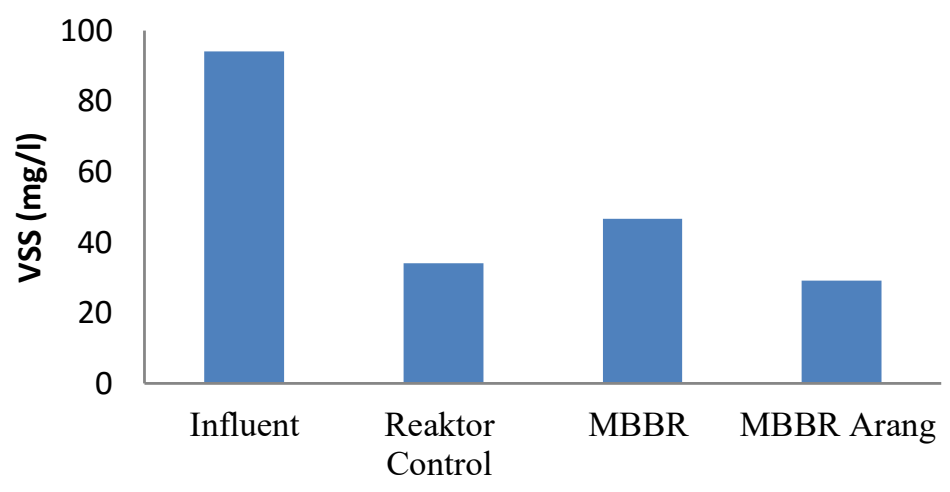

Gambar 8. Hasil analisis lindi awal dan akhir pengolah

VSS merupakan besarnya bahan organik dari tersuspensi (TSS) yang dihilangkan melalui pembakaran di dalam furnance dengan suhu $550^{\circ} \mathrm{C}$ selama 1 jam. VSS digunakan untuk mengetahui banyaknya padatan bahan organik pada suatu limbah. Bahan organik adalah sisa bahan atau limbah yang dapat diuraikan secara sempurna oleh proses biologi. Semakin tinggi VSS semakin sulit mengendap air limbah. Karena itu dilakukan pengolahan untuk menurunkan kandungan VSS pada lindi. Hasil pengolahan kandungan VSS pada lindi dapat dilihat pada gambar 10. Pengolahan berhasil menurunkan kandungan VSS pada lindi menjadi lebih rendah. Pada pengolahan menggunakan reaktor MBBR kandungan VSS berhasil diturunkan menjadi $34 \mathrm{mg} / \mathrm{l}$ dari VSS lindi awal $94 \mathrm{mg} / \mathrm{l}$, begitu juga dengan pengolahan menggunakan filter arang berhasil menurnkan kandungan lindi menjadi $29 \mathrm{mg} / \mathrm{l}$. Penurunan VSS menunjukkan bahwa didalam reaktor terjadi degradasi senyawa organik oleh mikroorganisme. 


\section{KESIMPULAN DAN SARAN}

\section{Simpulan}

Biofilm memberi pengaruh dalam menurunkan bahan pencemar lindi, pengolahan yang efektif dari ketiga metode adalah pengolahan dengan menggunakan MBBR yang dikombinasikan dengan arang karena mampu menurunkan bahan pencemar lebih banyak.

\section{Saran}

Sebaiknya dilakukan penelitian lanjutan dengan menambahkan bakteri aktif (activated sludge) dalam proses pengolahan dan juga menambahkan agitator atau pengaduk untuk memaksimalkan hasil pengolahan yang diperoleh.

\section{DAFTAR PUSTAKA}

Abuzar, S.S. dkk. 2012. Koefisien Transfer Gas (K1a) pada proses aerasi menggunakan Tray Aerator Bertingkat 5 (lima). Jurnal Teknik Lingkungan UNAND 9 (2) : 15 155-163 (Juli 2012).

Aziz, S.Q., H.A. Aziz, M.S. Yusoff , M.J.K Bashir, M. Umar. 2010. Leachate characterization in semi-anaerobik and anaerobic sanitary landdills: A comparative study, Journal of Environmental Management, 91:2608-2614.

Budiman. 2006. Pengantar Kesehatan Lingkungan. EGC, Jakarta.

Burke, D.A. 2010. Dairy Waste Anaerobic Digestion Handbook Option for Recovering Beneficial Product from Diary Manure. Olympia, WA: Enviromental Energy Company.

Djajadiningrat AH.Wisjnusuprapto. 1991. Bioreaktor Pengolahan Limbah Cair. JurusanTeknik Lingkungan. FakultasTeknikSipildanPerencanaan. ITB, Bandung

Hungtae, R.E. 1966. The Rumen and its Microbe. Department of Bacteriology.Academic Press. New York.

Hunt, B., 1996. Fine Bubble. Mechanical Aeration” Woodard \& Curran.

Kusumawati, T. 2012. Kajian Degradasi Air Tanah Dangkal Akibat Air Lindi (Leachate) Di Lingkungan Tempat Pembuangan Akhir Putri Cempo Surakarta. Tesis. Program Pasca Sarjana Universitas Sebelas Maret, Surakarta.

Mays, L. W. 1996. Water Resources Handbook. McGraw Hill, NewYork.

Moertinah, S., 2010. Kajian Proses Anaerobik Sebagai Alternatif Teknologi Pengolahan Air Limbah Industri Organik Tinggi. Jurnal Riset Teknologi Pencegahan Pencemaran Industri, 1(2), pp.104-114.

Pohland, F.G dan S.R. Harper. 1985. Critical Review and Summary of Leachate and Gas. Production from Landfills U.S Environmental Protection Agency, Ohio.

Qdais, A. dan A.A. Alsheiradeh. 2008. Kinetics of solid waste biodegradation in laboratory lysimeters. Jordan Journal of Civil Engineering, 2 (1):20-25.

Said, N.I. and Hartaja, D.R.K. 2018. Pengolahan air lindi dengan proses biofilter anaerobaerob dan denitrifikasi. Jurnal Air Indonesia, 8(1).

Siregar, S.A. 2005. Instalasi Pengelolaan Air Limbah.Penerbit Kanisius, Yogyakarta.

Umaly, R.C. dan Ma L.A. Cuvin. 1988. Limnology: Laboratory and field guide,Physicochemical factors, Biological factors. National Book Store,Inc. Publishers. Metro Manila.322p. 